\title{
The Distribution of Authority Regulation by Local Governments in Effort to Manage Marine Resources In Indonesia
}

\author{
Rosita Candrakirana ${ }^{1}$, Tri Hayati ${ }^{2}$, Harsanto Nursadi ${ }^{3}$, Djohemansyah Djohan ${ }^{4}$ \\ University of Indonesia ${ }^{23}$, University of Sebelas Maret-Indonesia ${ }^{1}$, Institute of Governance of Home \\ Affairs-Indonesia ${ }^{4}$ \\ \{rositakiranafhuns@gmail.com\}
}

\begin{abstract}
Management of Marine Resources in Indonesia is regulated in Act no. 22 of 1999, Act no. 32 of 2004, and Act no. 23 of 2014. These three regulations apply a concept that prefers the General Competence Principle or Doctrine of Ultra Vires. The research method performed normative with a statute approach and the analytical technique used qualitative. Given the results of this study, it shows that the current management of marine resources by the local government favors the doctrine of ultra vires through the elimination of marine management authority by the regency/city government. It affects the psychological aspect of local governments to make an optimal contribution to the management of marine resources in their respective area. For this reason, it is necessary to balance the application of the General Competence Principle or Doctrine of Ultra vires to create an amicable relationship between the central government, provincial governments, and regency/city governments.
\end{abstract}

Keywords: Authority, Local Government, Management, Marine

\section{Introduction}

Natural resources in Indonesia can be explored in the ocean and land. Indonesian geographical condition as an archipelagic country consists of two-third ocean area of Indonesia territory [1]. Based on a study by the Corruption Eradication Commission on Natural Resources in the marine sector, shows that the contribution of non-tax state revenues (PNBP) only earns 0.3 percent per year on average. For instance, the contribution of PNBP from the Fisheries sector in the last five years gains 0.02 percent of the total national tax revenue [2].

For this reason, fishermen in Indonesia are deemed as a community group with the highest poverty rate. In line with the results of a study by the Ministry of Maritime Affairs and Fisheries (KKP), the amount of poor population in Indonesia is dominated by residents in coastal areas. To this date, the figure has reached 7.9 million people, or 25 percent of the total poor people in Indonesia [3]. These aspects construct awareness on how inadequate the marine management so far. 
The shifting of regency/city authority in the natural resource management, especially in the marine sector, is a result of Act no. 23 of 2014 which will bring losses to the natural resources located in regencies/cities. Some of the potential losses that may occur include:[4]

a. The negligence of regency/city government towards natural resources;

b. The minimum function of district/city government guidance and supervision;

c. The big potential conflict between the provincial government and the regency/city in the natural resource management, particularly the marine sector.

Thus, it is necessary to examine the setting of the authority distribution of marine management in local government on the concept of General Competence and Doctrine of Ultra Vires to optimize the role of local governments in the marine resource management in Indonesia.

\section{Research Method}

This research is a case of normative legal research, which is a scientific method for determining the truth based on legal scholarship from a normative perspective. In this context, positive legal research encompasses multiple terms that essentially mean the same thing, including doctrinal research [5]. Fundamentally, doctrinal research is a library-based study; the materials necessary for the study are sourced from libraries, archives, and other databases. The overarching purpose of research is to acquire and share new knowledge and ideas, as well as to suggest improvements and adjustments [6].

In respect to normative legal research, the Statute Approach is a method for examining several legal regulations that serve as the study's focus and central concept [7]. The data analysis technique employed in this study is qualitative data analysis, which entails gathering data, qualifying it, then connecting relevant theories and forming inferences to ascertain the outcomes. The second phase is data analysis, which is used to convert study findings into a report.

\section{Result and Discussion}

Article 33 (3) of the 1945 Constitution regulates the government's jurisdiction in managing natural resources, especially the marine sector. Paragraph 3 of Article 33 is the legal basis for all statutory regulations governing the use and management of natural resources, especially maritime resources.

(1) The authority relations between the central government and regional authorities of provinces, regencies, and municipalities, or between a province and its regencies and municipalities, shall be regulated by law, taking into account the particularities and diversity of each region. (2) The central and regional governments' financial, public service, and resource relations are regulated and administered in accordance with the law.

Local Government Act Nos. 22 (1999), 32 (2004), and 23 (2014) are based on the regional autonomy provisions in the Republic of Indonesia's 1945 Constitution. These rules control the province's and regency/power city's to manage natural resources, particularly maritime resources. The following table details the authority granted to province, regency, and local administrations over marine management: 
Table 1. Regional Government Authority in Management

\begin{tabular}{|c|c|c|}
\hline Act No. 22 of 1999 & Act No. 32 of 2004 & Act No. 23 \\
\hline 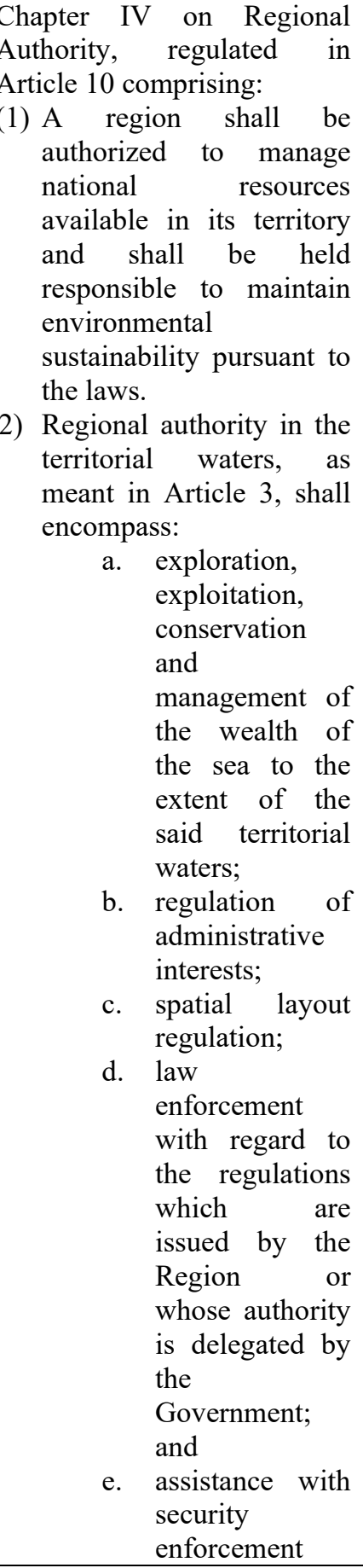 & $\begin{array}{l}\text { Chapter III on The } \\
\text { Distribution of } \\
\text { Administrative Affairs, } \\
\text { regulated in Article } 18 \\
\text { comprising: } \\
\text { 1) Registrations that have } \\
\text { sea territory are given } \\
\text { the authority to } \\
\text { manage resources in } \\
\text { the sea territory. } \\
\text { The regions deserve to } \\
\text { receive a portion of } \\
\text { proceeds from the } \\
\text { management of natural } \\
\text { resources beneath the } \\
\text { seabed and/or in the } \\
\text { seabed in accordance } \\
\text { with the legislation. } \\
\text { The authority of the } \\
\text { regions to manage } \\
\text { resources in the sea } \\
\text { territory as meant in } \\
\text { paragraph (1) covers: : } \\
\text { a. exploration, } \\
\text { exploitation, } \\
\text { conservation, and } \\
\text { management of } \\
\text { marine resources; } \\
\text { The authority to } \\
\text { f. participation in } \\
\text { defending the } \\
\text { administrative } \\
\text { control; sources in } \\
\text { c. spatial layout } \\
\text { control; } \\
\text { d. law enforcement } \\
\text { related to the } \\
\text { regulations issued } \\
\text { by the regions or } \\
\text { delegated by the } \\
\text { government; } \\
\text { maintaining } \\
\text { security; and }\end{array}$ & 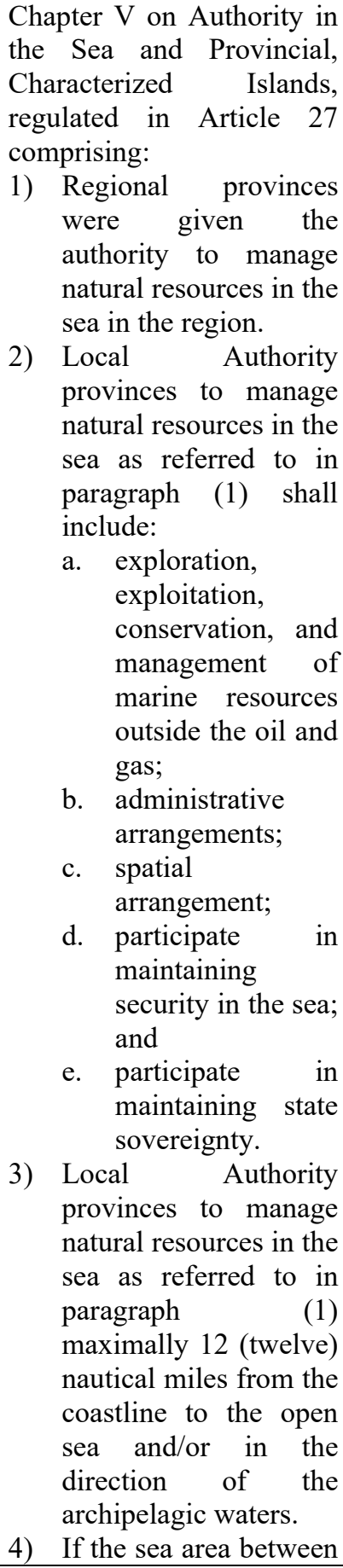 \\
\hline
\end{tabular}




\begin{tabular}{|c|c|c|c|}
\hline $\begin{array}{l}\text { and sovereignty. } \\
\text { (3) The authority of } \\
\text { regencies and } \\
\text { municipalities in the } \\
\text { territorial waters as meant } \\
\text { in sub-article (a) shall be } \\
\text { to an extent equal to one } \\
\text { third of the sea boundary } \\
\text { of a province. } \\
\text { (4) Further regulation of the } \\
\text { provision as meant in } \\
\text { sub-article (2) shall be } \\
\text { stipulated in a } \\
\text { government regulation. }\end{array}$ & 5) & $\begin{array}{l}\text { the sea territory as } \\
\text { meant in paragraph ( } 3 \text { ) } \\
\text { must not exceed } 12 \\
\text { (twelve) miles } \\
\text { measured from the } \\
\text { coastline to the open } \\
\text { sea and/or to the } \\
\text { waters of island for } \\
\text { provinces and } 1 / 3 \text { (one } \\
\text {-third) of the authority } \\
\text { territory of a province } \\
\text { for } \\
\text { regencies/municipaliti } \\
\text { es. } \\
\text { If the sea territory } \\
\text { between } 2 \\
\text { province is less tha) } \\
24 \text { (twenty four) miles, } \\
\text { the authority to } \\
\text { manage resources in } \\
\text { the sea territory will be } \\
\text { divided at the same } \\
\text { distance or measured } \\
\text { in accordance with the } \\
\text { principle of media line } \\
\text { from the area between } \\
\text { the } 2 \text { (two) provinces, } \\
\text { with the } \\
\text { regencies/municipaliti } \\
\text { es receiving } 1 / 3 \text { (one- } \\
\text { third) of authority } \\
\text { territory of the said } \\
\text { province. } \\
\text { The provisions in } \\
\text { paragraph (4) and } \\
\text { laid down in the } \\
\text { legislation. } \\
\text { apply to fish caught by } \\
\text { small fishermen. } \\
\text { The implementation of } \\
\text { provision in paragraph } \\
\text { (1) and paragraph ( } 3 \text { ), } \\
\text { paragraph (4), and } \\
\text { to }\end{array}$ & $\begin{array}{l}\text { the two provinces } \\
\text { Regions of less than } \\
24 \text { (twenty four) miles, } \\
\text { the authority to } \\
\text { manage natural } \\
\text { resources in the sea is } \\
\text { divided equally } \\
\text { distance or measured } \\
\text { according to the } \\
\text { median line between } \\
\text { the two regions of the } \\
\text { province. provisions } \\
\text { The in } \\
\text { referred to } \\
\text { paragraph (3) and (4) } \\
\text { does not apply to } \\
\text { fishing by fishermen. }\end{array}$ \\
\hline & & & $\begin{array}{l}\text { The regional government } \\
\text { in regencies/cities has no } \\
\text { authority in the sea area. }\end{array}$ \\
\hline
\end{tabular}


People from different backgrounds had an impact on how and what those laws on local government were set up and what they said. Act no. 5 of 1974, which had a centralist pattern to how it was set up, led to a tug of war between the interests of the national government and the interests of the regional governments [8]. It happened because the law didn't say which governments had the power to manage marine resources. So, the central government made and enforced Act 22 of 1999, which said the regency and city government had to have all the power.

Since Act 22 of 1999 came into effect, there was a pattern of authority that made it more likely for people at the bottom to have more power [9]. Act No. 22 of 1999, which was passed in 1999, was the first law in Indonesia to set out the basic rules for the management of the sea. It gives the provinces and regencies and cities the authority to manage the sea up to 12 miles from the lowest tidal sea, 12 miles from the baseline to the high seas, and one-third of the maritime boundaries of the provinces.

The implementation of decentralization in Indonesia has changed a lot since 1999, when Act No. 22 of 1999 was passed. This law gives Indonesians a lot of power, especially when it comes to managing marine resources. People are able to do this because Act No. 22 of 1999 limits government activities at the central and provincial levels through Government Regulation No. 25 of 2000. Then, through a recognition mechanism, regencies and cities can do the rest.

The way government affairs are split up is based on the idea of residual functions, which are given to the regency/city level, while government affairs at the central and provincial levels are clearly and specifically defined in Government Regulation 25/2000. Because the regency/city has a lot of power over the rest of the things that the provincial level doesn't have, it means that the regency/city has a lot of power over the rest of the things that the provincial level doesn't have [11].

Based on this, the law should be thought of as moving Indonesia closer to a federal system because regency/city governments are in charge of a lot of government business. Then, Act No. 22 of 1999 was changed to Act No. 32 of 2004 because of the reasons above. This law is seen as the start of the process of taking back government jobs that were previously done by the local governments. Act No. 32 of 2004 is thought to be a good balance between centralization and decentralization by the government. Act No. 32 of 2004 tries to make it easier for people to figure out where government business goes. It also stays within the broad autonomy (general competence) setting that exists at the regional level, both provincial and regency/city.

Legislation that came from Act No. 32 of 2004 split up government responsibilities between the central government, provincial governments, and local governments. Regulation No. 38 of 2007 is a part of that law. However, Act No. 32 of 2004 gives the power to manage marine resources to the provincial and regency/city governments. Regional Government Law aims to limit the power of local governments when it comes to managing marine resources, giving some of the power to the central government.

Based on the explanation above, the regulation regarding the affair distribution in Act no. 32 of 2004 is stipulated in detail in Government Regulation No. 38 of 2007. This regulation remains using the paradigm of affair distribution with the doctrine of ultra vires. The dominant pattern of the authority distribution in this law is doctrine of ultra vires. It can be found in Articles 10, 11, 12, 13, and 14 despite the Article 2 paragraph (3) states the widest possible autonomy [13]. This distribution pattern results in several impacts, among others: 1) there might be a tug of war of authority between provinces and regencies/municipalities in certain fields of affairs. 
Even though there are criteria for the affair distribution, yet problems still arise; 2) there is no encouragement towards autonomous regions to develop optional affairs because they do not choose but have to be creative, which must deal with the Government; 3) it is difficult to determine whether a future development of affairs other than those specified in the appendix is included in residual or optional affairs; 4) the determination of Co-Administration tends to be limited in the annex to the Government Regulation so there is no thought about whether the provisions outside the annex Government Regulation, another Co-Administration can be carried out; 5) there is no definite settlement of the authority conflict in the autonomous regions whose territories are bordered by an authority or special area[14].

Changes regarding the authority distribution between the center and the regions within the Act in lieu of Act no. 32 of 2004, namely Act no. 23 of 2014 that refers to the 2011 text revision of Act no. 32 of 2004 are carried out with the purpose of strengthening the weaknesses in Act No. 32 of 2004 [15]. With regard to the relationship of authority contained in Law no. 23 of 2014, there is a concept of autonomy contained in this law, namely broad autonomy and narrow autonomy [16]. The concept of broad autonomy is more based on the residual function which focuses on local government. It denotes that broad autonomy applies when all government affairs become the authority of the regions other than those determined by the central government.

In addition, autonomy is deemed limited if household affairs are determined in a categorical manner and their development is regulated in certain ways. The distribution and relationship of the central government with local governments' authority as regulated in Act no. 23 of 2014 obviously do not reflect broad autonomy. It is because the new Regional Government Law does not apply the residual function which assigns a very broad autonomy authority (general competence). The residual distribution system was adopted in the previous regulation, namely Act no. 22 of 1999.

However, since Act no. 32 of 2004, the residual function system began to be abandoned and changed to the concurrence function system. In this system, it is believed that there are matters of central authority and concurrent affairs which are distributed equally between the central government, provincial governments, and regency/city governments. Then, Act no. 23 of 2014 re-adopted this system with more detailed arrangements than the previous law. In addition to that, this law provides a provision that the Norm, Standard, Guidelines, and Criteria (NSPK) is determined by the central government. Therefore, Act no. 23 of 2014 adheres to the doctrine of ultra vires which limits autonomy. So, the concept of authority distribution in this law adheres to the principle of limited autonomy. It influenced the marine management authority contained in Article 27 which only assigns management authority to the provincial government while the regency/city governments do not bear the authority.

According to The Liang Gie, the detailed authority delegation system as adopted by Act no. 23 of 2014 has prompted poor psychological consequences. The regions appear to always depend on the enlightenment of the Central Government to be able to carry out any affairs. As a result, regions with a lot of initiatives and a strong desire to develop feel constrained by the policies of the Central Government. On the other hand, the Central Government is reluctant to give the widest possible autonomy to the regions as every leader wishes to have full authority, even, wants to broaden his power [18].

\section{Conclusion}

According to the marine resource management from the beginning of authority distribution from 1999 to 2014, it is necessary to balance the concept between the general competence principle and the doctrine of ultra vires so that local governments are able to provide optimal 
contributions without being constrained in exercising their authority to manage marine resources. In addition, an amicable relationship between the central government and regional governments as well as provincial governments and district/city governments can be established.

\section{Acknowledgments}

I would like to express my deepest gratitude to Universitas Sebelas Maret to grant this research.

\section{References}

[1] Marhaeni Ria Siaombodo, Hukum Perikanan Nasional dan Internasional, Jakarta : PT Gramedia Pustaka Utama, hlm.1, 2010.

[2] https://www.kpk.go.id/id/component/content/article/79-berita/berita-media/2689-selamatkan-sdakelautan, diakses 24 oktober 2017.

[3] http://www.kabarbisnis.com/read/2847678/25--penduduk-miskin-tinggal-di-kawasan-pesisir, diakses 24 Oktober 2017

[4] Yanis, Rinaldi, Kewenangan Kabupaten/Kota Dalam Pengelolaan Sumber Daya Alam Di Aceh Pasca Lahirnya Undang-Undang Nomor 23 Tahun 2014, Prosiding Seminar Nasional Hukum Lingkungan "Pengelolaan Sumber Daya Alam", Fakultas Hukum Universitas Hasanuddin Bekerjasama dengan Perkumpulan Pembina Hukum Lingkungan Indonesia dan Pustaka Pena Pers, hlm. 53-55.

[5] Terry Hutchinson, 2002, Researching and Writing in Law, Lawbook Co, Pyrmont NSW, hlm. 9 Dalam Johnny Ibrahim, Teori dan Metodologi Penelitian Hukum Normatif, Malang: Bayumedia Publishing, hlm.44, 2006.

[6] Anwarul Yaqin, Legal Research and Writing, Malaysia : LexisNexis, hlm. 10, 2011.

[7] Johnny Ibrahim, Teori dan Metodologi Penelitian Hukum Normatif, Malang: Bayumedia Publishing, hlm. 303, 2006.

[8] Rikardo Simarmata dan Asep Yunan F, Pemberlakukan Undang-Undang No. 23 Tahun 2014 dan Desentralisasi di Bidang Pengelolaan Sumber Daya Alam, Jakarta: Perkumpulan Untuk Pembaharuan Hukum Berbasis Masyarakat dan Ekologis (HUMA), hlm.7, 2016.

[9] H.A.S Natabaya, Analisis Evaluasi Hukum Tentang Otonomi Daerah Dalam Kaitannya Dengan Wilayah Pesisir dan Laut, Jakarta : Badan Pembinaan Hukum Nasional Departemen Hukum dan PerUndang-Undangan RI, hlm. 12, 1999/2000.

[10] H.A.S Natabaya, Analisis Evaluasi Hukum Tentang Otonomi Daerah Dalam Kaitannya Dengan Wilayah Pesisir dan Laut, Jakarta : Badan Pembinaan Hukum Nasional Departemen Hukum dan PerUndang-Undangan RI, hlm. 12, 1999/2000.

[11] Naskah Akademis revisi terhadap Undang-Undang No. 32 Tahun 2004 tentang Pemerintahan Daerah.

[12] Rikardo Simarmata dan Asep Yunan F, Pemberlakukan Undang-Undang No. 23 Tahun 2014 dan Desentralisasi di Bidang Pengelolaan Sumber Daya Alam, Jakarta: Perkumpulan Untuk Pembaharuan Hukum Berbasis Masyarakat dan Ekologis (HUMA), hlm.7, 2016.

[13] Irfan Ridwan Maksum, Perbandingan Sistem Pembagian Urusan Pemerintahan Antara Pemerintah Pusat dan Daerah Otonom, Laporan penelitian DSF Bank Duni, 2015, hlm.32.

[14] Irfan Ridwan Maksum, Perbandingan Sistem Pembagian Urusan Pemerintahan Antara Pemerintah Pusat dan Daerah Otonom, Laporan penelitian DSF Bank Duni, 2015, hlm.32.

[15] Abdul Rauf Alauddin Said, Pebagian Kewenangan Pemerintah Pusat-Pemerintah Daerah Dalam Otonomi Seluas-luasnya Menurut UUD 1945, Fiat Justisia Jurnal Ilmu Hukum Volume 9 No. 4, Oktober-Desember 2015,hlm. 592 
[16] Bagir Manan Dalam Abdul Rauf Alauddin Said, Pebagian Kewenangan Pemerintah PusatPemerintah Daerah Dalam Otonomi Seluas-luasnya Menurut UUD 1945, Fiat Justisia Jurnal Ilmu Hukum Volume 9 No. 4, Oktober-Desember 2015,hlm. 597.

[17] Abdul Rauf Alauddin Said, Pebagian Kewenangan Pemerintah Pusat-Pemerintah Daerah Dalam Otonomi Seluas-luasnya Menurut UUD 1945, Fiat Justisia Jurnal Ilmu Hukum Volume 9 No. 4, Oktober-Desember 2015,hlm. 597.

[18] The Liang Gie, Pertumbuhan Pemerintahan Daerah di Negara Republik Indonesia (Suatu Analisa tentang Masalah-Masalah Desentralisasi dan Tjara-tjara Penjelesaiannja) Jilid III ,Djakarta : PT. Gunung Agung, hlm 61-62, 1968. 